\section{Keterampilan Menulis Surat Pribadi Bahasa Jerman}

\author{
Nursyahbani Tenri Waru', Ambo Dalle \\ Universitas Negeri Makassar
}

Email: nursyahbanitenriwaru@gmail.com

Abstrak. Penelitian ini adalah penelitian deskriptif kuantitatif yang bertujuan untuk mengetahui tingkat keterampilan menulis surat pribadi siswa. Sampel peneltian ini adalah siswa kelas XII Bahasa SMA Negeri 1 Watansoppeng berjumlah 20 siswa dan merupakan sampel total. Sumber data dalam penelitian ini adalah siswa kelas XII Bahasa SMA Negeri 1 Watansoppeng. Data penelitian ini diperoleh melalui tes keterampilan menulis surat pribadi kemudian data dianalisis menggunakan teknik persentase. Hasil penelitian ini menunjukkan bahwa keterampilan menulis surat pribadi siswa berada pada kategori cukup $(71,45 \%)$ yang didukung oleh faktor internal yakni 18 siswa (90\%) gemar menulis karangan menggunakan bahasa Jerman dan faktor eksternal dimana 19 siswa (95\%) menyatakan guru selalu memberikan materi yang berkaitan dengan latihan menulis bahasa Jerman adapun fakor penghambat dalam keterampilan menulis surat pribadi siswa berasal dari faktor internal yakni 14 siswa (70\%) kesulitan dalam menyusun kalimat bahasa Jerman.

Kata Kunci: Keterampilan menulis, surat pribadi, bahasa Jerman
INTERFERENCE

Journal of Language,

Literature,and

Linguistics

\section{E-ISSN: 2721-1835 \\ P-ISSN: 2721-1827}

$\begin{array}{ll}\text { Submitted } & : \text { May } 5^{\text {th }}, 2021 \\ \text { Accepted } & : \text { May } 25^{\text {th }}, 2021\end{array}$

Abstract. This research is a descriptive quantitative research which aims to determine the skill level of students' personal letter writing. The sample of this research is the 12th grade students of SMA Negeri 1 Watansoppeng is 20 students and the sample is total sampling. The data in this research were students of class XII Language SMA Negeri 1 Watansoppeng. The research data were obtained through a personal letter writing skill test and the data were analyzed using the percentage technique. The result of this research that the students' personal letter writing skills is in the sufficient category (71.45\%) and the results of the questionnaire analysis show at percentage of 18 students (90\%) like to write German and it is also supported by external factors where 19 students (95\%) stated that the teacher always provides gives excerise about German writing skills while the inhibiting factor in students' personal letter writing skills comes from internal factors which is 14 students (70\%) struggling in composing German sentences. 


\section{PENDAHULUAN}

Menulis adalah kegiatan yang dilakukan guna menyalurkan gagasan atau ide pikiran melalui tulisan. Menulis memiliki peran yang sangat penting untuk meningkatkan kreatifitas dalam mengumpulkan informasi yang efisien dan efektif untuk menjangkau hal yang lebih luas.

Keterampilan menulis adalah keterampilan yang digunakan untuk menghasilkan sesuatu yang disebut tulisan. Dalam proses pembelajaran, keterampilan ini bisa diwujudkan dalam bentuk materi menulis dengan berbagai indikator. Sebagaimana materi lainnya, materi ini seharusnya disajikan secara bertahap karena menulis merupakan keterampilan lanjutan yang cukup kompleks.

Berdasarkan hasil wawancara peneliti dengan guru bahasa Jerman di SMAN 1 Watansoppeng pada tanggal 5 November 2019 dapat disimpulkan bahwa menulis merupakan salah satu keterampilan yang sulit bagi sebagian besar siswa dalam berbahasa asing, khususnya bahasa Jerman. Siswa seringkali mengalami kesulitan dalam mencurahkan ide dan pikirannya dalam bentuk tulisan.

Hasil penelitian yang berkaitan dengan menulis telah dilakukan oleh Suryono (2012) berada pada kategori cukup. Karissi (2014) dalam penelitiannya menunjukkan berada pada kategori baik dan Irhana (2015) berada pada kategori cukup. (Alvionicha, F., Jufri, J., \& Dalle, A., 2021; Andira, A., Hasmawati, H., \& Mantasiah, R., 2020; Nur, M., Burhanuddin, B., \& Mannahali, M. 2021; Sakkir, G., 2020; Syaputra, A. F., Mantasiah, R., \& Rijal, S.,2021 ) dan masih berada pada kategori cukup.

Keterampilan menulis surat pribadi merupakan keterampilan lanjutan dalam kompetensi berbahasa. Keterampilan merupakan suatu keahlian yang dimiliki oleh seseorang sehingga dapat menghasilkan sesuatu yang bernilai. Menurut Prastowo (2015:200) keterampilan adalah materi atau bahan pembelajaran yang berhubungan dengan antara lain kemampuan mengembangkan ide, memilih, menggunakan bahan, menggunakan peralatan, dan teknik kerja.

Menulis adalah suatu kegiatan dan keterampilan produktif untuk siswa yang belajar bahasa Jerman guna mengekspresikan ide atau gagasan yang dicurahkan dalam bentuk tulisan. Menulis menurut Aziz (2009:7) adalah suatu proses yang menggunakan lambang-lambang huruf untuk menyusun, mencatat dan mengkomunikasikan serta dapat menampung aspirasi yang dapat menghibur dan memberikan informasi kepada orang lain. Senada dengan Aziz, Dalle, dkk (2019:90) mengemukakan bahwa keterampilan menulis adalah salah satu aspek berbahasa produktif yang sangat penting. Dengan menulis manusia dapat memberikan informasi yang merupakan hasil dari ide, gagasan, dan pemikiran secara tertulis.s

Keterampilan menulis adalah suatu kemampuan mencurahkan gagasan atau ide dengan dalam bentuk tulisan. Awing dan Saleh (2017:29) mengatakan bahwa keterampilan menulis adalah kemampuan mengungkapkan pendapat dengan menggunakan kosakata, gramatik dan ejaan untuk berkomunikasi dengan pihak lain secara tidak langsung. Menurut Satata dalam Satata, dkk (2019:9) keterampilan menulis adalah kemampuan mengekspresikan pikiran melalui lambang-lambang tulisan. 
Menulis adalah kegiatan berkomunikasi melalui simbol huruf dengan memerhatikan tata bahasa. Menulis memiliki tujuan berdasarkan kegunaannya masing-masing. Menurut Soedjito dalam Aziz (2009:11) tujuan menulis adalah mengeskpresikan perasaan, memberi informasi, mempengaruhi pembaca, memberi hiburan.

Tulisan terbagi menjadi beberapa jenis. Lebih lanjut, Huy T,N (2015: 54) mengatakan bahwa terdapat enam jenis tulisan diantaranya:"Exposition; Exposition is one of four rhetorical mode of discourse, along with argumentation, description and narration Argumentation: Argumentation is the interdisciplinary study of how humans should, can, and do reach conclusions through logical reasoning; Description: Description is one of four rhetorical modes (also known as modes of discourse); Narration; Narration is some kind of retelling, often in word. Narration recounts events, perhaps leaving some occurences out".

Menulis berperan penting sebagai rantai penghubung dalam menyampaikan ide atau karangan orang lain. Dalam kegiatan menulis terdapat langkah-langkah yang harus dilakukan Grieshammer (2006:8) mengemukakan:

"Phasen des Scheribprozesses: Schreibsituation und Schreibbegründung, Schreibplanung, schreiben, bewerten, Überarbeiten, und Veröffentlichung". Pendapat di atas dapat diartikan bahwa tahapan proses penulisan terdiri atas menulis situasi dan menulis alasan, strategi menulis, menulis, meninjau, merevisi dan menerbitkan

Dalam keterampilan menulis terdapat faktor-faktor pendukung yaitu faktor internal dan ekstermal. Slameto (2015:54) menyatakan faktor internal dalam keterampilan menulis adalah kesehatan dan motivasi. Menurut Djaali (2017:99) faktor eksternal dalam keterampilan menulis diantaranya: “Keluarga;. Lingkungan sekitar; Sekolah; Faktor yang ada dalam lingkungan sekolah terdiri dari rendahnya peran guru dalam membina siswa agar terampil menulis. Kurangnya sentuhan dalam memberikan strategi menulis yang tepat.

Menulis surat adalah kegiatan yang dilakukan untuk berkomunikasi secara tertulis. Surat pribadi adalah surat yang ditulis untuk memberikan informasi yang bersifat pribadi. Secara umum, surat terbagi dalam beberapa jenis. Kosasih (2019:97) mengatakan surat terbagi atas tiga jenis diantaranya surat pribadi, surat dinas, dan surat niaga. Menurut Kosasih (2019: 97) surat pribadi adalah surat yang ditulis atas nama pribadi atau perorangan.

Surat yang baik memiliki bagian - bagian yang telah ditentukan. Dalman (2018:273) menyatakan bagian-bagian surat yang harus diperhatikan adalah kepala surat, nomor surat, tanggal, bulan dan tahun surat, lampiran, hal atau perihal, alamat surat, salam pembuka, isi surat, salam penutup, jabatan penulisan surat, tanda tangan, nama terang, tembusan, dan inisial.

\section{METODE PENELITIAN}

Penelitian ini adalah penelitian deskriptif kuantitatif yang bertujuan memberikan gambaran atau informasi, serta faktor yang memengaruhi keterampilan menulis surat pribadi siswa dalam menulis surat pribadi bahasa Jerman kelas XII Bahasa SMA Negeri 1 Watansoppeng.

Penelitian ini dilaksanakan pada semester ganjil tahun ajaran 2020/2021, tepatnya pada 16 November 2020 dilaksanakan di SMA Negeri 1 Watansoppeng 
yang terletak di Jalan Samudra No.2, Kelurahan Botto, Kecamatan Lalabata, Kabupaten Soppeng yang dilakukan secara daring melalui aplikasi whatsapp.

Subjek yang diteliti adalah siswa kelas XII Bahasa SMA Negeri 1 Watansoppeng yang berjumlah 20 orang. Adapun objek yang akan diteliti adalah keterampilan menulis surat pribadi berdasarkan aspek isi, organisasi, kosa-kata, penggunaan bahasa, dan mekanik pada siswa kelas XII Bahasa SMA Negeri 1 Watansoppeng tahun ajaran 2020/2021.

Populasi penelitian ini adalah seluruh siswa SMA Negeri 1 Watansoppeng. Sampel pada penelitian ini adalah kelas XII Bahasa SMA Negeri 1 Watansoppeng dengan jumlah 20 (total sampel).

Data penelitian ini adalah tes menulis dan angket. Jenis angket yang digunakan adalah angket tertutup. Data tersebut dinilai berdasarkan aspek isi, organisasi, kosa kata, penggunaan bahasa, dan mekanik. Instrumen yang digunakan dalam teknik pengumpulan data penelitian ini melalui tes menulis surat pribadi dalam bahasa Jerman dan angket. Penelitian dilakukan secara daring melalui aplikasi whatsapp. Siswa mengisi angket melalui google form.

Teknik penilaian yang digunakan berdasarkan skor penilaian menulis dari Nurgiyantoro (2017) dan patokan penilaian Nurgiyantoro (2012:253). Untuk menganalisis data dan angket digunakan rumus persentase sebagai berikut:

Rumus presentase :

$$
\mathrm{X}=\frac{f n}{\Sigma f} \times 100
$$

Keterangan:

$X$ : Frekuensi kesalahan

$f n$ : Jumlah kesalahan

$\Sigma f$ : Jumlah keseluruhan kesalahan

(Sudjana 2008:67)

Selanjutnya, untuk mencari skor rata-rata data dihitung dengan menggunakan rumus :

Keterangan:

$$
x=\frac{\sum x}{N}
$$

$$
\begin{array}{ll}
x & =\text { Skor rata-rata } \\
\sum x & =\text { Jumlah skor } \\
\mathrm{N} & =\text { Jumlah sampel }
\end{array}
$$

(Djiwandono 2011:218)

\section{HASIL DAN PEMBAHASAN}

Hasil distribusi nilai dari keterampilan menulis surat pribadi berdasarkan keseluruhan aspek isi, organisasi, kosa-kata, penggunaan bahasa dan mekanik dapat dilihat pada tabel di bawah ini: 


\begin{tabular}{|c|c|c|c|}
\hline NO & Rentang Nilai & Frekuensi & Persentase \\
\hline 1 & $55-61$ & 4 & $20 \%$ \\
\hline 2 & $62-68$ & 3 & $15 \%$ \\
\hline 3 & $69-75$ & 7 & $35 \%$ \\
\hline 4 & $76-82$ & 5 & $25 \%$ \\
\hline 5 & $83-89$ & 1 & $5 \%$ \\
\hline & Jumlah & 20 & $100 \%$ \\
\hline
\end{tabular}

Selanjutnya, masukkan ke dalam rumus rata-rata sebagai berikut:

$$
\begin{gathered}
\qquad x=\frac{\sum X}{N} \\
\left.x=\frac{1429}{20}=71,4 \text { (skor maksimal seluruh aspek adalah } 100\right)
\end{gathered}
$$

Keterangan:

$x \quad=$ Skor rata-rata

$\sum x=$ Jumlah skor

$\mathrm{N} \quad=$ Jumlah sampel

Setelah mendapatkan skor rata-rata, selanjutnya dimasukkan ke dalam teknik persentase dengan hasil $71,45 \%$

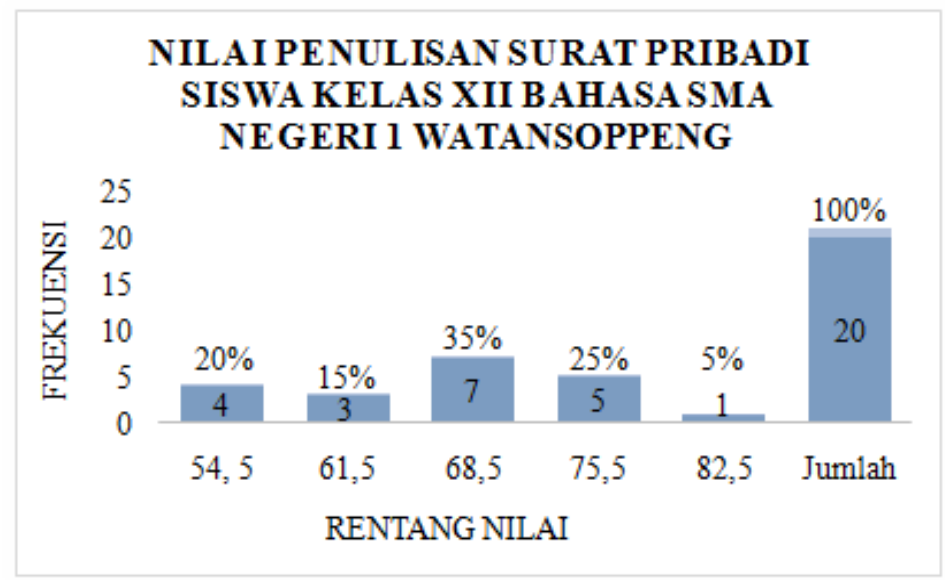

Distribusi skor di atas dapat dideskripsikan bahwa diketahui 4 siswa berada pada rentang skor $55-61$ dengan persentase $20 \%$. Selanjutnya terdapat 3 siswa berada pada rentang skor 62- 68 dengan persentase 15\%. Diketahui terdapat 7 siswa yang berada pada rentang skor $69-75$ dengan persentase 35\%. Diketahui terdapat 5 siswa berada pada rentang skor $76-82$ dengan persentase $25 \%$. Jumlah siswa pada rentang skor $83-89$ adalah 1 siswa dengan persentase $5 \%$. Dapat disimpulkan bahwa persentase tertinggi berada pada rentang skor 69 - 75 yakni 35\% dan persentase terendah berada pada rentang skor $83-89$ yakni $5 \%$.

Berdasarkan hasil perhitungan di atas dapat disimpulkan bahwa keterampilan menulis surat pribadi siswa kelas XII Bahasa SMA Negeri 1 Watansoppeng berada pada kategori cukup (71,45\%). 


\section{Hasil Analisis Aspek Surat}

\section{a. Aspek isi surat}

Siswa menulis surat dengan tema die Familie sesuai dengan instruksi yang diberi. Berdasarkan aspek isi surat pada penelitian ini terbilang baik dikarenakan siswa mengerjakan soal dengan cukup jelas. Siswa menuliskan perkenalan diri, nama orang tua, jumlah saudara, dan hobi. Keterampilan menulis surat pribadi bahasa Jerman yang dilakukan oleh siswa kelas XII Bahasa SMA Negeri 1 Watansoppeng pada aspek isi berada pada kategori baik (75,5\%).

\section{b. Aspek Organisasi Surat}

Hasil dari aspek organisasi surat yang dikerjakan oleh siswa kelas XII Bahasa SMA Negeri 1 Watansoppeng terbilang baik. Gagasan yang diungkapkan siswa di surat tersebut dapat dipahami meskipun ada beberapa siswa yang kurang teliti dalam menulis surat seperti lupa menulis tanggal, nama pengirim surat maupun penerima surat yang akan ditujukan. Hasil persentase dari aspek organisasi surat siswa kelas XII Bahasa SMA Negeri 1 Watansoppeng beradapada kategori cukup (73\%).

\section{c. Aspek Kosa-kata}

Hasil surat yang ditulis oleh siswa dapat ditemukan beberapa kesalahan kosakata. Berdasarkan temuan peneliti kosakata siswa masih perlu untuk dikembangkan karena siswa masih terbatas dalam mengemukakan ide. Berdasarkan temuan peneliti maka keterampilan menulis surat pribadi bahasa Jerman yang dilakukan oleh siswa kelas XII Bahasa SMA Negeri 1 Watansoppeng pada aspek kosakata berada pada kategori cukup (71,25\%).

\section{d. Aspek Penggunaan Bahasa}

Penggunaan bahasa dari hasil kerja siswa dapat dikatakan bahwa sudah cukup terstuktur tetapi masih terdapat beberapa kesalahan kata dari kalimat yang ditulis serta masih terdapat beberapa kalimat berulang. Keterampilan menulis surat pribadi bahasa Jerman yang dilakukan oleh siswa kelas XII Bahasa SMA Negeri 1 Watansoppeng pada aspek penggunaan bahasa berada pada kategori cukup $(68,4 \%)$.

\section{e. Aspek Mekanik}

Berdasarkan hasil kerja siswa diketahui bahwa terjadi kesalahan ejaan tetapi terdapat juga siswa yang menggunakan ejaan dengan tepat dan telah menggunakan tanda baca serta huruf kapital dengan benar. Keterampilan menulis surat pribadi bahasa Jerman yang dilakukan oleh siswa kelas XII Bahasa SMA Negeri 1 Watansoppeng pada aspek mekanik berada pada kategori kurang (56\%).

f. Hasil Keseluruhan Keterampilan Menulis Surat Pribadi Siswa Kelas XII Bahasa SMA Negeri 1 Watansoppeng.

Berdasarkan hasil analisis data menunjukkan bahwa siswa menulis surat dengan baik. Berdasarkan hasil dari aspek isi, siswa menulis seluruh instruksi soal yakni perkenalan diri, nama orang tua, jumlah saudara dan hobi. Berdasarkan aspek 
organisasi surat diketahui bahwa gagasan yang diungkapkan siswa dapat dipahami tetapi masih ada siswa yang kurang teliti dalam menulis surat seperti lupa menuliskan tanggal, nama pengirim, dan nama penerima surat yang akan dituju. Berdasarkan aspek kosakata ditemukan beberapa kesalahan kosakata yang dimana masih perlu untuk dikembangkan karena siswa masih terbatas dalam mengemukakan ide. Berdasarkan aspek penggunaan bahasa terdapat kalimat yang ditulis secara berulang tetapi bentuk kalimat sudah terstruktur dan berdasarkan aspek mekanik siswa masih terdapat kesalahan ejaan tetapi ada beberapa siswa yang sudah menggunakan ejaan dengan tepat dan menggunakan huruf kapital dengan tepat.

Berdasarkan hasil penelitian, dapat disimpulkan bahwa keterampilan menulis surat pribadi siswa kelas XII Bahasa SMA Negeri 1 Watansoppeng berada pada kategori cukup (71,45\%) yang didukung dengan angket yang disebar menunjukkan 18 siswa (90\%) gemar menulis karangan menggunakan bahasa Jerman dan faktor eksternal dimana 19 siswa (95\%) menyatakan guru selalu memberikan materi yang berkaitan dengan latihan menulis bahasa Jerman adapun fakor penghambat dalam keterampilan menulis surat pribadi siswa berasal dari faktor internal yakni 14 siswa (70\%) kesulitan dalam menyusun kalimat bahasa Jerman.

\section{KESIMPULAN}

Berdasarkan hasil yang telah diperoleh dari pembahasan sebelumnya dapat disimpulkan bahwa keterampilan menulis surat pribadi bahasa Jerman siswa kelas XII Bahasa SMA Negeri 1 Watansoppeng berada pada kategori cukup (71,45\%) yang didukung oleh angket yang disebar diketahui faktor internal yakni 18 siswa (90\%) gemar menulis karangan menggunakan bahasa Jerman dan faktor eksternal dimana 19 siswa (95\%) menyatakan guru selalu memberikan materi yang berkaitan dengan latihan menulis bahasa Jerman adapun fakor penghambat dalam keterampilan menulis surat pribadi siswa berasal dari faktor internal yakni 14 siswa (70\%) kesulitan dalam menyusun kalimat bahasa Jerman dengan persentase.

\section{DAFTAR PUSTAKA}

Alvionicha, F., Jufri, J., \& Dalle, A. (2021). Keterampilan Menulis dan Berbicara Bahasa Jerman Siswa Berbasis Model Pembelajaran SAUD. Interference: Journal of Language, Literature, and Linguistics, 2(1), 1-10.

Andira, A., Hasmawati, H., \& Mantasiah, R. (2020). PENERAPAN MODEL PEMBELAJARAN KOOPERATIF TIPE STAD (STUDENT TEAM ACHIEVEMENT DIVISION) DALAM KETERAMPILAN MENULIS KALIMAT SEDERHANA BAHASA JERMAN. Interference: Journal of Language, Literature, and Linguistics, 1(2), 128-133.

Awing, I., and Saleh, N. (2017) "Keefektifan Model Pembelajaran Kooperatif Tipe Concept Sentence dalam Keterampilan Menulis Karangan Deskripsi Bahasa Jerman Siswa Kelas XI IPA SMA Negeri 12 Makassar." Eralingua: Jurnal Pendidikan Bahasa Asing dan Sastra 1.1

Aziz, A. (2009). Menulis Lanjut. Jawa Barat: YAF Garut. 
Dalle, A, Anwar M., and Asri, W. K. (2019). "Penerapan Media Flashcard dalam Pembelajaran Keterampilan Menulis Karangan Bahasa Jerman." Indonesian Journal of Educational Studies 22.2 89-93.

Dalman. (2018). Keterampilan Menulis. Depok: PT. Rajagrafindo Persada.

Djaali. (2017). Psikologi Pendidikan. Jakarta: PT . Bumi Aksara.

Djiwandono, S. (2011). Tes Bahasa. Jakarta: Indeks.

Grieshammer, E. (2011). Der Schreibprozess beim wissenschaftlichen Schreiben in der Fremdsprache Deutsch und Möglichkeiten seiner Unterstützung. Frankfurt: Europa-Universität Viadrina Frankfurt (Oder). https://opus4.kobv.de/ diakses tanggal 17 April 2021

Huy, N. T. (2015). "Problems affecting learning writing skill of grade 11 at Thong Linh high school." Asian Journal of Educational Research 3.2

Irhana. (2015). Hubungan Antara Penguasaan Kosakata dengan Keterampilan Menulis Surat Pribadi Bahasa Jerman Siswa Kelas XI Bahasa SMA Negeri 1 Bontonompo Kabupaten Gowa. Skripsi: Fakultas Bahasa Dan Sastra Jurusan Bahasa Asing Universitas Negeri Makassar

Karissi, Y. (2014). Keterampilan Menulis Surat Pribadi Dalam Bahasa Jerman Pada Siswa Kelas XI SMA Negeri 1 Sesean Kabupaten Toraja Utara.

Kosasih, E. (2019). Dasar-dasar Keterampilan Menulis. Bandung: Yrama Widya.

Nur, M., Burhanuddin, B., \& Mannahali, M. (2021). Hubungan Antara Penguasaan Kosakata dengan Keterampilan Menulis Puisi Bahasa Jerman. Interference: Journal of Language, Literature, and Linguistics, 2(1), 64-70.

Nurgiyantoro, B. (2012). Penilaian Pembelajaran Bahasa Berbasis Kompetensi. Yogyakarta: BPFE-Yogyakarta.

Nurgiyantoro, B. (2017). Penilaian Pembelajaran Bahasa Berbasis Kompetensi. Yogyakarta: BPFE-Yogyakarta.

Prastowo, A. (2015). Panduan Kreatif Membuat Bahan Ajar Inovatif. Yogyakarta: Diva Press.

Sakkir, G. (2020). The Effectiveness of Pictures In Enhance Writing Skill of Senior High School Students. Interference: Journal of Language, Literature, and Linguistics, 1(1).

Satata, S.,dkk. (2019). Bahasa Indonesia Untuk Perguruan Tinggi. Jakarta: Mitra Wacana Media

Slameto. (2015). Belajar dan Faktor yang Mempengaruhinya. Jakarta: Rineka Cipta.

Sudjana. (2008). Metode Statistik. Jakarta: Bina Aksara.

Suryono, M. A. (2012). Keterampilan Menulis Surat Dalam Bahasa Jerman Siswa SMA Negeri 8 Makassar. Skripsi: Fakultas Bahasa Dan Sastra Jurusan Bahasa Asing Universitas Negeri Makassar.

Syaputra, A. F., Mantasiah, R., \& Rijal, S. (2021, March). Web-Based Mentimeter Learning Media in Learning German Writing Skills. In International Conference on Science and Advanced Technology (ICSAT). 